The Lure of the Edge 
This page intentionally left blank 


\section{The Lure of the Edge}

Scientific Passions, Religious Beliefs, and the Pursuit of UFOs

Brenda Denzler

UNIVERSITY OF CALIFORNIA PRESS

Berkeley · Los Angeles · London 
University of California Press

Berkeley and Los Angeles, California

University of California Press, Ltd.

London, England

(C) 200 I by

The Regents of the University of California

Library of Congress Cataloging-in-Publication Data

Denzler, Brenda, I953-

The lure of the edge : scientific passions,

religious beliefs, and the pursuit of UFOs /

Brenda Denzler.

p. $\mathrm{cm}$.

Includes bibliographical references and index.

ISBN 0-520-22432-9 (cloth : alk. paper)

I. Alien abduction. 2. Human-alien encounters. 3. Unidentified flying objectsReligious aspects. 4. Religion and scienceMiscellanea. I. Title.

BF2050.D466 $200 \mathrm{I}$

$001.942-\mathrm{dc} 2 \mathrm{I}$

2001027670

Printed in the United States of America

08070605040302 OI

IO $98765432 \mathrm{I}$

The paper used in this publication is both acid-free and totally chlorine-free (TCF). It meets the minimum requirements of ANSI/NISO Z39.48-I992 (R 1997) (Permanence of Paper). $\otimes$ 
To Connie M.,

who allowed me to conceive of the impossible,

and to the late John Trechak,

who didn't laugh at me when I did. 
This page intentionally left blank 
The Soul of Man . . . comprehendeth all ages in a moment, and unless it perceive something more excellent, is very desolate. All worlds being but a silent wilderness, without some living thing more sweet and blessed after which it aspireth.

Thomas Traherne, Centuries, \#62 
This page intentionally left blank 